\section{Nuclear Behaviour in Migrating Cells of the Rat's Corneal Epithelium}

WHILE conducting a series of experiments on the healing of needle pricks applied to the corneal epithelium of albino rats, perforating the epithelium only, it was seen that migration and proliferation of cells occur simultaneously, and before the commencement of mitosis. Mulliple injuries were made. The eyes were then left to heal in the animal for varying periods after injury and, after removal, fixation and staining with hæmatoxylin, cross-sections were made and examined in series.

As is known, in these minute wounds migration of cells of the wound wall and around the wound commences roughly one and a half hours after application ${ }^{1}$. My investigations revealed an occasional split nucleus in a migrating cell one and a half hours after injury.

Two hours after application, and before any appreciable mitotic activity of the cells could be detected, there was considerable increase in the num. ber of cells of the wound wall. This increase was manifested by an annular prominence of the epithelium of the wound wall, around the wound hole, made up of cells with clearly discernible membranes, of varying size, for the greater part smaller than average, although cells of average and more than average size were seen, too. Exceptionally, cells of a size much greater than that of ordinary epithelial cells were encountered.

Among the cells of average or more than average size, some with split nuclei or nuclei with furrows were often found. The occasional very large cells were always either bi- or tri-nucleate, or the nuclei displayed one or more furrows. Split nuclei were not limited to cells of the basal layer. Although infrequently, abnormal mitoses were sometimes seen. These could not be detected one and a half hours after injury.

Three hours after injury, a fair number of abnormal mitoses were observed in the annular prominence. Occasionally, these occurred in layers other than the basal. Many approached the appearance of normal figures more than did those two hours after injury. Cells with split nuclei persisted.

At times a normal mitotic figure was found in the normal epithelium between the wounds.

Four hours after application of the injury many normal mitoses were seen in the epithelium between the wounds. In the annular prominence cells with split nuclei and abnormal mitoses persisted.

That there is strong inhibition of mitosis following such injuries of the corneal epithelium in rats was found by Friedenwald and Buschke ${ }^{1}$. They state that in vivo a return to normal count is found around the fourth hour and some overshooting occurs between four and six hours after injury.

From the above it was concluded that, as in this instance there is cell proliferation without any normal mitotic figures present, cell multiplication has occurred by a process other than mitosis. Consequently, injury as such causes a change in the mode of cell division in the immediate vicinity of a wound.

Further, from a detailed study of the mechanism of wounding ${ }^{2}$ which showed that, at least in a certain area, the only injury to the migrating cells is through compression, it was concluded that, of itself, compression of the epithelium produces a change in the mode of cell division.
'This work received financial support from the Council for Scientific and Industrial Research, South Africa.

Zoology Department,

$$
\text { Johanna C. HeERema }
$$

University of Cape Town.

Sept. 7.

${ }^{1}$ Friedenwald, J. S., and Buschke, W., J. Cell. and Comp. Phys., 23, 95 (1944).

${ }^{2}$ Heerema, J. (to be published).

\section{Influence of Atropine and Morphine on the Liberation of Acetylcholine from the Guinea Pig's Intestine}

Ir has been shown by Chujyo ${ }^{1}$ that distension of the lumen of the guinea pig's intestine results in ar increased output of acetylcholine. Distension of the lumen also leads to a contraction of the longitudinal muscle, which is probably brought about by the acetylcholine released. Atropine and morphine abolish this contraction; but the mechanism of the action of these two drugs appears to be different. The following experiments show that whereas atropine apparently acts by preventing the action of the released acetylcholine on the longitudinal muscle, morphine inhibits the release of acetylcholine.

Distended strips of the guinea pig's small intestine were incubated in Tyrode solution aerated with 95 per cent oxygen +5 per cent carbon dioxide at $38^{\circ} \mathrm{C}$. in the presence of $10 \mu \mathrm{gm} . / \mathrm{ml}$. eserine. Four samples were obtained from the intestine of one animal; two were incubated in the presence of atropine or morphine, the other two served as controls. After $1 \mathrm{hr}$. incubation the Tyrode solution was removed, cooled, made isotonic to frog saline and assayed for acetylcholine on the eserinized frog rectus muscle. $1 \mathrm{gm}$. of intestinal tissue released between 2 and $6 \mu \mathrm{gm}$. acetylcholine per $\mathrm{hr}$. The same release, or an insignificant increase in the release, was obtained when the experiment was carried out in the presence of $5 \mu \mathrm{gm} . / \mathrm{ml}$. atropine in the bath fluid. On the other hand, the presence of $10 \mu \mathrm{gm} . / \mathrm{ml}$ morphine in the Tyrode solution reduced the output of acetylcholine by $40-60$ per cent although morphine is 3-5 times less effective in paralysing the guinea pig's ileum than atropine ${ }^{2}$. These results are given in Table 1; each figure represents the mean of two samples.

The present observation agrees with the corresponding one of Paton $^{3}$, who found that the output of acetylcholine from the intestine on co-axial electrical stimulation of the guinea pig's ileum was depressed by morphine.

The effect of morphine in preventing the release of acetylcholine brought about by distension or stimulation of the gut is best explained on the assumption that the acetylcholine is released from nerve fibres or nerve endings which are inhibited by

Table 1

\begin{tabular}{|c|c|c|c|c|c|}
\hline & \multicolumn{3}{|c|}{ Liberation of acetylcholine* $(\mu \mathrm{gm} . / \mathrm{gm} . / \mathrm{hr})}$. \\
\hline Exp, & Control & $\begin{array}{c}\text { Atropine } \\
\text { No. }\end{array}$ & $\begin{array}{c}\text { Exp. } \\
\text { No }\end{array}$ & Control & $\begin{array}{c}\text { Morphine } \\
(10 \mu \mathrm{gm} . / \mathrm{ml} .)\end{array}$ \\
\hline 1 & $2 \cdot 55$ & $2 \cdot 30$ & 5 & $2 \cdot 25$ & 1.35 \\
2 & 2.75 & 3.20 & 6 & 3.00 & 1.35 \\
3 & 5.95 & 6.50 & 7 & $5 \cdot 30$ & $2 \cdot 25$ \\
4 & 4.90 & $5 \cdot 10$ & 8 & $5 \cdot 00$ & $2 \cdot 15$ \\
& & & 9 & $4 \cdot 10$ & 1.60 \\
\hline
\end{tabular}

* Expressed in terms of acetylcholine chloride. 